\title{
Examining the relationship of Corruption with Economic Growth, Poverty and Gender Inequality Albanian Case
}

\author{
Jonada Tafa \\ Epoka University \\ jonadatafa@gmail.com
}

\begin{abstract}
This thesis examines the relationship of corruption with economic growth, poverty and gender inequality in Albania. Albania is a developing country with a GDP growth rate of 1.6\% (World Bank, 2012) and income inequality is a serious problem that government has to deal with. Regarding gender discrimination a lot of progress is made. The current government counts six female ministers in its body. Corruption in Albania is a widespread phenomenon and is found almost in every sector of life. TI CPI index ranks Albania in the 116 place out of 177 countries observed. To study this relationship a multiple regression analysis is conducted. Data for this analysis correspond to years 2000 to 2012 and is accessed from World Bank database. in this analysis CC from World Bank is the dependent variable, while FDI, GDP growth rate, GNI per Capita, Unemployment Rate, Proportion of Women in Parliamentary Positions and Women's share in Labor Force Participation Rate are the explanatory variables. The first two variables are used as indicators of economic growth. GNI per capita and Unemployment rate account for poverty, while the last two variables account for gender inequality. The results have shown that when the level of FDIs in Albania is increased government performance in control of corruption is improved. From the analysis it is understood that a decrease in unemployment rate would increase government performance in control of corruption. The results of the analysis showed that when unemployment rate increase, CC decreases. Regarding the link of corruption with GDP growth rate and GNI per capita, an inverse relationship is observed. With an increase in either GDP growth rate or GNI per capita, CC will decrease. Even the relationship with number of women in parliament and their share in labor force participation rate with corruption resulted to be negative. An increase in either proportion of women in parliamentary positions or share of them in labor force participation rate has shown to worsen government performance in control of corruption.
\end{abstract}

Keywords: corruption; economic growth; income inequality; gender inequality

\section{Introduction}

This paper aims at explaining the relationship that exists among corruption and economic growth, corruption and poverty, and corruption and gender inequality in Albania.

Albania is a transition country, which left communist regime in early ' 90 s. Under that regime its economy was closed. With the collapse, from 1992 to 1996 Albania experienced a good economic growth, having the highest economic growth rate compared to it of other transition countries in that period. in 1997 with the civil war that captured the country economy entered into collapse and the transition period was extended until today. Unemployment rate in 2013 was registered $14.7 \%$, which is a very high rate. Agriculture is the main sector, generating the largest percentage of GDP. Corruption has always been a serious problem for the country. It is one of the most important factors that impede its integration into European Union. According to TI, Albania was placed in the 116th place out of 177 countries taken in observation. On overall country is perceived to be highly corrupted. To understand this condition, this paper tries to explain the level of corruption in the country through Economic Growth, Poverty and Gender Inequality. Income inequality is a very serious problem, since the bottom part of the population merely earns money to get feed. Gender discrimination is another issue that should be taken into consideration, even though a lot of progress has been made in this aspect.

The first section is an introduction of the main topics to be discussed in this paper. This section tries to give the definitions of each topic, corruption, economic growth, poverty and gender inequality. After defining it, then it tries to explain the factors affecting each subject and in the end it deals with methods used to measure those. Because of its illegal nature measuring corruption is very difficult. To measure it different international organizations have established some well-known indexes such as: Corruption Perception Index of $\mathrm{TI}$, Control of Corruption index by World Bank etc.

The second part is the literature review on the relationship of corruption with economic growth, poverty and gender inequality. The relationship between economic growth and corruption is studied in two directions, economic growth effect on corruption and corruption effect on economic growth. Some studies reveal that corruption impedes economic growth 
and other reveal the contrary. However, the results differ because of different conditions taken into consideration, such as the country of observation, culture of that country and other uncontrolled factors which may have contributed to such results. When examining the effect of corruption in economic growth most of the studies conclude that when corruption decreases economy performs better. The link between corruption and poverty has two sides. Corruption deepens poverty, but poverty may also lead to corruption. Studies made all over the world show a direct relationship between poverty and corruption, implying that an increase in poverty will increase corruption in that country. Regarding gender inequality and its relationship with corruption there are different views. Some argue that when the number of women in high managing and leading positions is high, level of corruption is low. However, some studies contravene these results, showing a negative relationship between number of women in high positions and corruption. It should be noted that these results differ because when studying this relationship, different variables are taken into consideration. It should not be forgotten the fact that females are differently treated and seen in different countries and situations.

The last part of this study is the analysis of these relationships in Albania. A regression analysis is performed, with CC index of World Bank as dependent variable and FDI, GDP growth rate, GNI per capita, Unemployment rate, Proportion of women having a seat in the parliament and women's share in labor force participation rate as independent variables. The dataset consists on data for the years 2000 to 2012. These data were accessed from World Bank database. It should be mentioned that in this study no data from Albanian sources was taken, to avoid the biasness of the results.

\section{Background}

\section{Corruption}

Corruption is a problem which is seen in every country in the world, even though in different measures. There are many definitions about it. The most widely used one is that corruption refers to the misuse of power by public officials for personal gains, forgetting their responsibilities and duties. Transparency International defines corruption as: 'Corruption is the abuse of entrusted power for private gains. It hurts everyone who depends on the integrity of people in a position of authority' (Transparencylnternational, 1993). According to world banks' corruption is 'the misuse of public office for private gain' (World Bank, 1997).

Industrial revolution is one those historical events which have contributed in the development of corruption. During this period the so-called white collar crime appeared. Industrial revolution was followed by a great financial growth. Because of this financial growth, economy became more dependent on finance and investments (Lanch \& Rob, 1992). This dependency was followed by the development of banking sector, stock and bond markets, and a new legal system. To sustain these developments, the number of financiers, lawyers and many other professionals was increased, which helped in a further expansion of white-collar crime.

Colonization is another source of corruption. Results of different researchers have shown that there is a strong relationship between colonies and corruption. This fact is seen more on countries where the companies created by colonies, have low property rights. According to a study made by Acemoglu, Johnson and Robinson in 2001, in those areas where a large number of Europeans were living, institutions created were used for their own benefit. Even today these countries suffer from high corruption levels.

One of the main reasons for involving in corruption is rent seeking. Many governments in Africa have been practicing kleptocracy. This is a practice in which personal interest comes first. People and many other resources are exploited and national interest is neglected. Governments in these countries put their friends and relatives in important political positions. This practice, nepotism, confronts the principle of meritocracy. in meritocracy people are rewarded for their abilities and capacities, without "references" from relatives and friends. Countries which do not apply this principle are governed by nonprofessionals. This results in an increase of corruption levels. Studies show that in those countries where government intervenes more, corruption is higher. Intervention of government includes quotas, tariffs, subsidiaries etc. Governments have full power on these instruments and may use them in a way that benefits them most.

Efficient institutions play an important role in fighting corruption. To increase efficiency of them, skilled and well-educated professional should be employed (C.North, 1991).An efficient institution means acting in accordance with law and without any outside or inside distracter. This way quality and stability of institution will increase.

Treisman in his research mentions as possible factors of corruption religion and old traditions (Treisman, 2000). Some researchers argue that in Catholic and Muslim countries the level of education is low, resulting in high levels of corruption. However, in my opinion religion does not influence corruption. Religious people are guided by Bible or Koran, in which corruption is seen as a sin. 
As almost everything that exists has two parts one black and one white, we can say the same thing about corruption. On one side it is seen as 'grease in the wheels of commerce', and on the other side it is seen as 'sand in the wheels of commerce'. According to Leff (Leff, 1989) corruption helps to speed up transaction process. By means of corruption new industries/firms will enter the market and will increase competition. On the other hand corruption is seen as a factor which impedes efficient allocation of resources. for example Kaufmann in his study in 1997 concluded that resources devoted to corruption could be invested elsewhere and probably this investment would bring a higher return and lower costs. Usage of bribes can be very costly. Bribery does not necessarily mean that what you have asked for will be fulfilled. As it is illegal, investors cannot sue the other party in a court.

Corruption is seen in different forms. Researches use five approaches to differentiate types of corruption. The first approach has to do with the position an individual has in an institution. Based on this approach we differentiate between 'upper-level' and 'lower-level' corruption. High-ranking officials are engaged in 'upper-level' corruption. On the other hand civil servants relate to 'lower-level' corruption. The main difference between these two types of corruption is the role or the position that the public official is holding. 'Political corruption' stands for corruption at the decision-making stage, while 'bureaucratic corruption' stands for corruption that occurs in implementation of policies and decisions.

The second approach has to do with the nature of transaction. This approach makes a distinction between 'bribery' and 'extortion'. Bribery is a situation in which an individual from general public makes an extra payment to public officials, to reach something he/she needs. On the other hand extortion is the case when public officials use their power and asks extra payments for providing a service.

Many scholars classify corruption in two forms: petty and grand corruption. Grand corruption, sometimes called as political corruption, refers to corruption at the highest level of governance. It includes people who have a large influence in political decision-making. It involves a large amount of money. Petty corruption, on the other hand, takes place at the lowest levels. in this level we have a direct contact between public officials and the general public and less money involved. This form of corruption is also very important because these small bribes, over time are amassed (Scott, 1972).

Corruption can also be differentiated based on the context of the act. This is systemic framework approach. According to (Robinson, 1998), there are three types of corruption: 'incidental corruption', which is very rare; 'institutional corruption', which refers to institutions that lack control and corruption is high; and 'systemic corruption', which is the case of society being too much involved in corruption practices.

Another approach distinguishes corruption based on motive or outcome from the act. Margarit Beare, in her research "Corruption and Organized Crime: Lessons from History" in 1997, recognizes four types of corruption based on motive/purpose approach. 'Bribes/kickbacks', used to get the right to do legitimate business; 'election/campaign corruption', which is that type of corruption used to guarantee ongoing power; 'protection corruption', is a situation when payments are offered in order to get protection from engaging in illegal businesses; 'systemic top-down corruption', is that form of corruption which relates to a systemic use of a nation's wealth by a ruling elite.

Corruption has been and is still very hard to measure. One reason for this difficulty is the illegality in its nature and different forms it is seen. Different international organizations have developed different indexes which help to measure it. Transparency International uses CPI (Corruption Perception Index), International Country Risk Group's has established a different index (ICRG).

Corruption is understood better when analyzing the relationship between corruption and poverty; corruption and gender inequality and corruption and economic growth. in the following sections, this paper will be focused on poverty, gender inequality and economic growth, specifically their definitions, types, factors and measurement.

\section{Poverty}

' 1 billion children live in poverty' (Shah, Global Issues, 2013). Statistics show us that poverty is increasing day by day. This phenomenon is present in the majority of world's population, in both developed and non-developed countries. Poverty covers a wide range of topics. It is not related only to poverty in terms of income, but also to health and wellbeing of individuals.

Different scholars have distinguishes three main types of poverty definitions: monetary poverty, multidimensional poverty and the capabilities approach (Misturelli \& Heffernan, 2008). Monetary poverty refers to poverty in terms of income. Capabilities approach is about what individuals can do with what they posses. 
On the other hand other researchers have divided poverty in to two main types: Absolute and Relative poverty. Absolute poverty, known also as extreme poverty, refers to a situation where people cannot satisfy even basic needs for living, like: food, clean water, houses, medicine etc. This kind of poverty is more common in poor countries, but not only. for example Roma living in European countries suffer from absolute poverty. Relative poverty is when there exit some differences in incomes and life styles of people in a society. in relative poverty people struggle to reach a minimum standard of living, defined by the rest of the society.

There are many factors behind poverty. Mainly poverty is the result of how society is structured. It also depends on individual factors.

Individual factors are classified as follow:

High Unemployment: This is an indicator of low or no income.

Inadequate Education level: This prevents people from getting employed in good positions and be better paid.

Minority Ethnic group: Members of these minority groups are discriminated and prevented to get access to decent jobs.

Disability: Disabled people have limited access to employment.

There are some other very important causes of poverty, which do not directly depend on individuals. These factors are related to historical events or functioning of the society.

Colonialism: Many scholars see this as very important factor, which has contributed to the level of poverty in the world. Colonizers have created some "local economies" so that they could exploit resources only for their economic growth. These countries lack a proper infrastructure, preventing interaction with other countries.

Power Centralization: This refers to centralization of political power. in many developing countries, politicians make decisions about regions they are not familiar with. This leads to inappropriate programs.

War: Beside numerous human deaths, war causes many material damages. Many fabrics, stores, roads are destroyed. in these situations, limited resources are used for military purposes, rather than to fight poverty.

Social Inequality: This social inequality has to do with discrimination done to individuals on basis of religion, ethnic and racial characteristics. There is the example of White and Black people, which based on their skin color they get or not the opportunity to work.

Corruption: This is another factor that contributes in advancement of poverty. This is related more with the situation, when public representatives use funds provided for public investments for their own benefit.

There are different ways to measure poverty. The most used way is to define a poverty line. This line differs from country to country. for example in poor countries this line varies from 1 to $2 \$$ per day. in developed countries poverty line is defined as having an income below a certain percentage of median income of a country. However, World Bank and OECD use even other indicators to measure poverty, like: birth rate, mortality rate, disease occurrence, households' conditions etc. $\mathrm{GINI}$ coefficient is another method used to measure poverty. It refers to measurement of disposal income inequality. A coefficient of 0 implies complete equality, while a coefficient of 1 means incomplete inequality. Beside disposal income, some other indicators like school enrollment, literacy rate, unemployment rate, migration rate etc, are included in Gini coefficient analysis.

\section{Gender Inequality}

Gender inequality has always been a hot topic for debates all over the world. If we have a look at the history, we can see a domination of male over the women. Even the 20th century situation, was seen to be the same. Women were meant to be home, taking care of children, while men were supposed to work and participate in public field.

Regarding the definition of gender inequality, I would like firstly to define what gender equality stands for. According to United Nations (United Nations, 2001) organization gender equality refers to equal rights, responsibilities and opportunities of women and men. Equality does not mean that women will became the same as men, but instead equal chances to develop will be given to both of them.

Gender inequality refers to discrimination made to men and women because of their gender. Generally this discrimination is addressed to women. They are seen inferior and less valuable just because of the fact they are women. But there are also some cases of discrimination made to men. 
In sociology this inequality sometimes is seen as a "natural" thing. This means that gender relations are not defined by the rule of the society, but instead biological characteristics. for example it is a fact that women are able to give birth to an infant, while men are not. However, these natural inequalities cannot be the reasons for the social relations between genders. in an egalitarian point of view, relations between genders are said to be pale if both men and women have equal power and autonomy.

As it was mention above, there exists a traditional division of labor within the household. Women are generally excluded from leadership positions, while on the other hand men are excluded from child care. Because of these divisions, there are formed some stylized facts of relative status of men and women (Mikkola \& A.Miles, 2007).

Relative status of women:

Son preference: in some countries female babies are valued less. This phenomenon is remarkably observed in regions of Asia, mainly in China, India and South Korea. Statistics show that this is also seen in western countries like USA, too. Number of divorced people, who have girl children, is higher than those having boy children. Lena Edlund in her study "Son Preference, Sex Rations, and Marriage Patterns" in 1999 has stated that son preference is explained by the parents utility perception. Males will be more helpful than women.

Education: for many decades women have been excluded from education in school and university. The first woman acceptance in university was in 1870 in the University of Helsinki. in developing countries literacy levels are lower in developing countries, even though significant progress has been made.

Employment and total work: Share of female workers in the total labor force has increased over the past years. We have more women employed in the service sector. Still, women are deprived from leadership positions. There are 192 countries in the world, but only 12 of them have as the head of the state a woman. Another interesting fact is that women are those who occupy the largest percentage of part time jobs, translated in lower incomes.

Decision making power: Women have always been striving to gain power. Even in western countries, like USA, women gained the voting right only in 1920, in the same year with Albania, which is still a still a transition country.

Status of men

Life expectancy: Men's life span on average is shorter than that of women. Only in some countries life expectancy between men and women is equal. This shorter life expectancy of men is related to life style of them. Men are those who are more engaged on suicide, war and narcotics usage.

Changing roles and marginalization: With the changing structure of the work in the developed countries, women started to work in the service sector. This sector was growing day by day, while men were working in declining sectors, like: manufacturing, agriculture etc. Because of this restructuring, an increase in women's relative wage is observed.

Gender inequality is seen as one the determinants that lead to corruption. One of the most challenging question of current debates is whether women are less corrupt than man are. Different researches have been made to analyze the impact that gender has on corruption. Some believe that women by nature are less corrupt than man. They have the fear of being detected and then discriminated by the public. Others oppose this fact, by arguing that women can be easily corrupted as they are easily manipulated. Further in this paper we will try to give an answer to this question.

\section{Economic Growth}

This section is about economic growth, its indicators, measurement and effect it has in the life of people. Economic growth is defined as the capability of a country to produce goods and services and distribute them among consumers. It is measured in real and nominal terms. in nominal terms, inflation is also included. Real economic growth is adjusted for inflation.

The most used indicators for measuring economic growth are GDP per capita and GNP per capita. These two indicators take into consideration even the population of a country. Gross domestic product (GDP) is the sum of the value of finished goods produced within a country in a specific year. GDP represents also personal consumption, government expenditures, private investments and net exports. Gross national product (GNP) includes GDP, plus income earned by residents in overseas investments, minus any income earned by foreigners within the country. GNP is a measure of country's performance, what its residents have produced and whether these products were produced within the boundaries of the country. 
In 1776 Adam Smith with his book "The wealth of nations" brought a new and fundamental perspective of economic growth theory. in the very first chapter of his book, he discussed on economic growth by explaining the importance of labor division. According to him, specialization would result in faster and more efficient growth. By taking the example of pins production, he argued that a single person would not be able to make 20 pins a day and ten workers at the end of the day would have finished less than 200 pins. However, if work is divided and different worker is assigned a different task, at the end of the day the same workforce would have finished about 48000 pins. Division of labor increases productivity, leading to higher wages. With high wages people demand more and markets expand further. As a conclusion, Smith's economic growth theory says that growth is mainly achieved by an increase in consumption. However, this growth cannot continue forever. Government intervention may impede the indefinite growth of economy, by policies like imposing a ceiling wage.

Most of the work on this topic has been done to define the causes and origin of economic growth. The three most important factors are physical factors, human capital and innovation. Solow explained capital accumulation as one of the most important indicators of economic growth. It is known as Solow Growth Model. in this model prices are not taken into consideration and everyone works all the time. This model is build under the assumptions that people work all the time and save a fixed proportion of their income. Economy is assumed as closed. Fundamental equation of growth: $(\mathrm{k}=\mathrm{s} * \mathrm{f}(\mathrm{k})-$ $(\mathrm{n}+\gamma+\delta) * \mathrm{k})$, where $\mathrm{k}$ stands for capital stock for worker, $\mathrm{s}$ for investment, $\mathrm{n}$ for population growth, $\gamma$ for technological progress and $\delta$ for depreciation. Population growth, technological progress and depreciation are inversely related to $\mathrm{k}$ (capital stock per worker). While investments are positively related to $\mathrm{k}$. Human capital is seen by many scholars as one of the most important factors of economic growth. It is the use of human capital that has helped economies recover from stagnation. According to different scholars studies the return to accumulating human capital increases with the stock of human capital (Roys \& Seshadri, 2014).

Regarding the origin of economic growth, there are two factors institutions and geography. It is believed that efficient working institutions help growing the economy. Institutions which operate on basis of meritocracy contribute in reducing corruption. Countries where corruption is in the lowest level have prove to have highest growth rates. Luxembourg is one of the countries with the highest GDP level in Europe and according to CPI of Transparency International organization, it is ranked the 11th among 177 countries (Transparency International, 2013). Regarding geographical position, those countries which are not favored by the climate are poorer compared to those countries favored by geography. There are countries like Sudan in Africa that face a negative growth rate, specifically GDP (real) in 2011 was -4, as registered in Indexmundi.

\section{Literature Review}

\section{Corruption and Poverty}

The relationship between corruption and poverty affects both individuals and businesses. It is a twofold relation: On one hand poverty encourages corruption, while on the other hand corruption intensifies poverty.

This relationship has been a subject for study since 1970s. Rent-seeking phenomenon influences people perceptions about the economic system. A few businesses would be able to survive if they did not use their power to influence government officials to make them favors in any case they need (O.Krueger, 1974). Price system is viewed as a mechanism which rewards the wealthy people and those who have connections with political representatives. This perception creates incentives for greater rent-seeking. A higher rent-seeking leads to an increase in economic activity. Corruption benefits some individuals more than others and as it deepens and affects government decisions in resource allocation, its distributional effects are more obvious (Gupta, Davoodi, \& Alonso Terme, 1998).

Corruption contributes to tax evasion, lack of effective tax administration and favors well-connected and wealthy people. for example the use of government funded programs for the benefit of the wealthy people will decrease the impact of social programs in income distribution and poverty level. Wealthy people with use their wealth 0 affect government to make them favors while conducting trade policies, for example special exchange rate, spending program and tax rate. in this way assets of wealthy people will have greater returns, compared to those assets owned by the poor. As assets can be used as collateral, the ability of the poor to borrow will decrease, contributing to a deeper income inequality and poverty. Corruption contributes to lower spending in health and education (Mauro, 1995). It prevents the poor people to get access to public services, because of their inability to pay bribes. Such things lead to an exacerbation of poverty. The wealthy people can corrupt government to increase investment in education for their benefit. The poor people have an extra risk premium, so the expected return on assets of wealthy people will increase. They will be discouraged to invest in any resources resulting in a deeper income inequality and poverty level. 
Because of corruption, public investments will shift from service sector to areas with higher profits, like construction and infrastructure. Lack of investments in service sector makes service providers to ask payments for services that should be offered for free or at low cost (USAID, 2005).

The link between corruption and poverty can be explained also by economic growth. High corruption is followed by a high poverty level. When economy is growing, people expectations are higher. Unemployment falls and income level starts to increase. Due to these changes people start to spend more and poverty reduces. But when this growth is associated by a high level of corruption, the opposite situation is observed. An increase in corruption will decrease economic growth. As a result poverty will increase and income inequality will be more rigid (Gupta, Davoodi, \& Alonso Terme, 1998).

In May 1998 IMF conducted a research to investigate the relationship between corruption and poverty. The result showed that corruption and poverty have a positive relationship with each other. A one percentage growth in rate of corruption decreases income growth by $7.8 \%$ for those people who fall on $20 \%$ of bottom population.

According to a study of World Bank, lower levels of corruption are associated with lowers levels of income inequality and costs of corruption are higher in small businesses (World Bank, 2000). The study was conducted to see if there is any relationship between corruption and income inequality, in Europe and Central Asian countries.

Susanne Karstedt (Karstedt, 2001) conducted a research in 35 OECD countries. Her aim was to examine the link between corruption and income distribution. Results showed that countries which have high income inequality have also high level of corruption. Whereas in countries education level is high and number of women in government positions is high, corruption has a decreasing trend. The relationship between corruption (Gini-Index) and income inequality was observed to be nonlinear, meaning that corruption will exponentially decrease after certain income equality is reached. Even though the level of income inequality is same in different countries, level of corruption is not the same. Fight against corruption has not been efficient in every country this is the reason why corruption between countries with same income inequality is different.

Income inequality increases corruption. Because of their status, privileges and their economic capacity, the rich people have both motivation and possibility to engage in bribes giving, while the poor people are somewhat excluded from this socalled privilege (You \& Khagram, 2004). in countries with totalitarian political regime, corruption is very high. However the effect of inequality is more severe in countries under democratic regimes.

In 2002 in Monterrey it was held Summit of Development Finance and since then worldwide is accepted that corruption increases poverty, or at least impedes efficiency of poverty reduction actions.

Political corruption has an indirect impact on provision of public services, while petty corruption used to access these services have a direct impact on poor households poverty level. These poor households are not able to find money to afford the public services offered, or are obliged to rely on incompetent professionals. in their effort to find money for such services, they actually deepen their poverty. They borrow money from different sources, which later they are not able to pay. They may take their children out of school or even cut back on food.

Corruption does not directly produce poverty. The relationship between them is indirect. Corruption has a direct effect on economic performance and governance, which are directly related with poverty (Chetwynd, Chetwynd, \& Spector, 2003). Anti-corruption measures if carefully implemented may result in important poverty reduction. in order to decrease poverty, these anti-corruption actions should also achieve an increase in economic growth, increase trust in government, improve public services etc.

\section{Corruption and Gender Inequality}

Many researchers and scholars place a great effort in determining the link between corruption and gender. Most believe that corruption affects men and women differently.

Women into government have benefit on society and decreases corruption in particular (Dollar et.Al, 1999). A higher rate of women in governmental position reduces corruption. Women are believed to behave less opportunistically and may have higher moral and ethical standards than men. As a result more women into government may benefit society in general. His study consisted of sample of 144 and 270 observations, for the period of 1982-1995. To account for participation of women in government share of seats in upper and lower chambers held by women is used. As an indicator of corruption level International Country Risk Guide Index (ICRG) is used.

This relationship between corruption and participation of women in government is explained by the concept of self-selection (Swamy, Knack, Lee, \& Azfar, 2001). There are a very few women who get to these important positions, and this is because these women are among the most distinguished ones. 
However the belief that women have higher ethical standards and thus are less corrupted than men is opposed by Goetz. She argues that such relationships exist because of limited access of women to political decisions. Generally corruption happens in all-male networks and women are excluded from these networks. When they enter in politics they are unfamiliar with such behaviors, such as bribes that would bring them personal benefit. Because of this reason they behave more ethically and with higher integrity. However, when the time passes and women become more familiar with such environments, this effect may fade away (Goetz, 2004).

Hung-en Sung attributed the belief that a higher e number of women in government decrease corruption to the well functioning of liberal institutions. A fairer system and not higher women integrity lead to less corruption (Sung, 2003). Liberal institutions provide better incentives for women participation in governmental positions. These kinds of institutions treat women equally, fairer and with tolerance. in this way women feel more committed to their work and do not engage in illegal exchanges. in her analysis when both gender differences and institutional indicators were included in the model, the effects of gender inequality on corruption become non-significant. This leads to the conclusion that is the degree of democracy within the institutions that affects more corruption and less gender differences.

An important factor that has been taken into consideration when examining the link between corruption and gender is discrimination against women. in countries where corruption is high, the level of discrimination against women is also high. in these countries it is seen a great preference for men in government positions.

Several studies argue that society's behavior against women shapes political life and the position of women in government. As politics has an important influence in corruption, one can argue that society's behavior against women has a great impact on corruption as well. in 2001 Trip made a research in analyzing the role of women in preventing corruption in Eastern and South Africa. Despite reforms made, improvements in competitive elections, freedom of expression and multiparty political system, women yet did not have enough access to higher positions. Women could enter in politics, but they could not access all-male networks and were excluded from the benefits of clientelistic networks. However, these reforms helped discriminated women to form some social groups. These groups organized independent movements. The aim of these movements was to increase transparency and remove such clientelistic networks that benefited men, and were an important source of corruption (Trip, 2001).

Importance is also given to attitudes against corruption, which determine its persistence. in $2006 \mathrm{~V}$. Alatas made a study on four countries Australia, India, Singapore and Indonesia. The results showed that there not difference in men and women's attitude against corruption. A greater variation was observed in women's attitudes toward corruption in different countries. These findings suggest that attitudes toward corruption are more related to culture than to gender differences (Alatas, 2008).

In studying the relationship between gender and corruption, it should be understood that corruption affects differently and takes different forms in men and women. These different effects are studied into three categories: access to decisionmaking power, protection of women rights and access to resources (Nawaz, 2009).

Corruption leaves women with little space to change their state. in countries where votes are bought, clientelism is on place and where people are awarded for their connections and not on basis of meritocracy, there are few chances for poor women to develop themselves (Kariuki, 2008).

The impact that corruption has on women access to resources is very deep. It can be analyzed in three different situations. The first case has to do with the relationship of grand corruption and access to public services such as health and education, to women. These services are more affordable for an advantaged part of the society. Poor women cannot afford the bribes asked for these services, this makes them become poorer or are left with few choices for such services. Another serious case is the sexual abuse in schools. This kind of corruption is not reported due to its nature. This leads to discrimination and prejudices against females, while the other party is not touched at all. This is the case when the effect of corruption on women is doubled: not only they pay the "bribe", but they also are in danger of being expelled from school. Most believe that women are unable to pay bribes so they are somehow "justified". This means that women may access some services without paying bribes, but not always. in most of the cases women do not get the service because they cannot penetrate inside the network where bribes are paid (Nawaz, 2009).

\section{Corruption and Economic Growth}

Effect corruption has on economic growth has two sides. Some researchers have concluded that it impedes economic growth, while others argue that it contributes to a faster growth.

Corruption contributes to economic growth by allowing individuals to use bribes in case where there are excessive and irrelevant regulations and to avoid unnecessary bureaucratic procedures (Leff, 1989). Corruption can reduce the time 
people waste in a queue (Lui, 1985). Excessive bureaucratic procedures slow down the process of business formation or because of the strict, inefficient rules individuals do not take advantage of all the resources available. in these cases corrupt officials may have a positive effect on growth, by reducing the barriers mentioned above. He also argued that some corruption may even enhance economic growth in countries with efficient rules.

The view of Lui that corruption has a positive effect on economic growth is contested by many other researchers. Bribery is not a legal process, so that officials who accept these bribes will help and enter in such relationships only with people they may know or believe in. This means that not necessarily using bribes will increase efficiency (Alaman, 1989).

From another perspective corruption hinders economic growth. When corruption is high it decreases both investments and economic growth (Mauro, 1995). His study consisted on cross-sectional data on different countries. However Mauro's conclusion is not universally supported because his findings rely on some specifications, which makes them sensitive to changes in these specifications.

Corruption has a negative effect on most macroeconomic indicators such as consumptions, employment, investments, exports/imports, spending of government and money market (Bendardaf, 1996). Bendardaf reached this conclusion by using Keynesian model. Lambsdorff also relies on Keynesian model and states that corruption impedes growth and worsens the effectiveness of investments (Lambsdorff, 1999).

Based on the growth model developed by Lucas in 1998, which explains that output is generated by the equation: $Y=A$ * $\mathrm{K}^{\propto}(\mathrm{u} * \mathrm{~h} * \mathrm{~L})^{1-\alpha}$, where $\mathrm{u}$ is the time workers spend on working and $\mathrm{h}$ is the human capital, effect of corruption on investments is negative and statistically significant in the same time, while the effect of corruption on economic growth is not significant (Brunetti, 1999).

Different studies support the fact that corruption decreases growth. However some exceptions are included. in a regression analysis when investment variable is controlled a negative link between corruption and growth is observed, but when education is controlled for the impact of corruption on growth is no more significant (Mo, 2001).

A study made on African countries showed that corruption decreases growth on one side and increase income inequality on the other side (Gyimah-Brempong, 2002). Corruption is seen as an important factor which reduces economic growth rate in Lebanon. When corruption index decreases GDP increases and GDP start to move to its steady state level. Corruption has a negative effect on living standards, investment and human capital in Lebanon. It also reduces effectiveness of government expenditures (Farida \& Ahmadi-Esfahani, 2006).

\section{Albanian Case}

\section{Albania}

Albania is one of the oldest countries in the Balkan region. It is located in the southeastern Europe and is bordered by Adriatic and Ionian Sea, Greece in the south and Montenegro and Kosova in the north. It gained its independence from Ottoman Empire in 1912. Until 1990s it has been under communist regime. in 1991 the first democratic elections were held. A lot of progress is made regarding the election process, but deficiencies do exist yet. in 2013 general elections were held and a government coalition between Socialist Party and The Socialist Movement for Integrity was formed. Albania joined NATO in 2009 and is a potential candidate for accession in EU. Despite reforms that are made corruption remains one of the biggest challenges of Albanian government.Before the crises of 2008, Albania was one of the fastest-growing developing countries, with a real GDP growth rate of $6 \%$, which was followed up by a decrease in poverty. But with the crises this changed. Unemployment in 2013 was calculated to be $16.9 \%$, while in 2012 it used to be $14.7 \%$. Agriculture is one of the most important sectors in Albania. 20\% of GDP is generated from this sector and about more than half of Albanians are employed there.

\section{Corruption in Albania}

Corruption is a widespread phenomenon in Albania. According to Transparency International corruption perception index Albania was ranked 116 out of 177 countries included in these ranking. Its score was 31 on a 0(vey corrupt) to 100(very clean) scale (Transparency International, 2013). On the other hand World Bank Control of Corruption Measurement in 2012 placed Albania in the 20-40 percentile rank. After the fall of communist system till 1996, Albania was doing quite good with respect to control of corruption. Then in 1997 with the civil war that captured the country the situation was changed as shown in Figure 1. Compared to its neighbor countries Montenegro, Serbia, Macedonia and Kosovo, Albania is performing worst. 


\section{Control of Corruption}

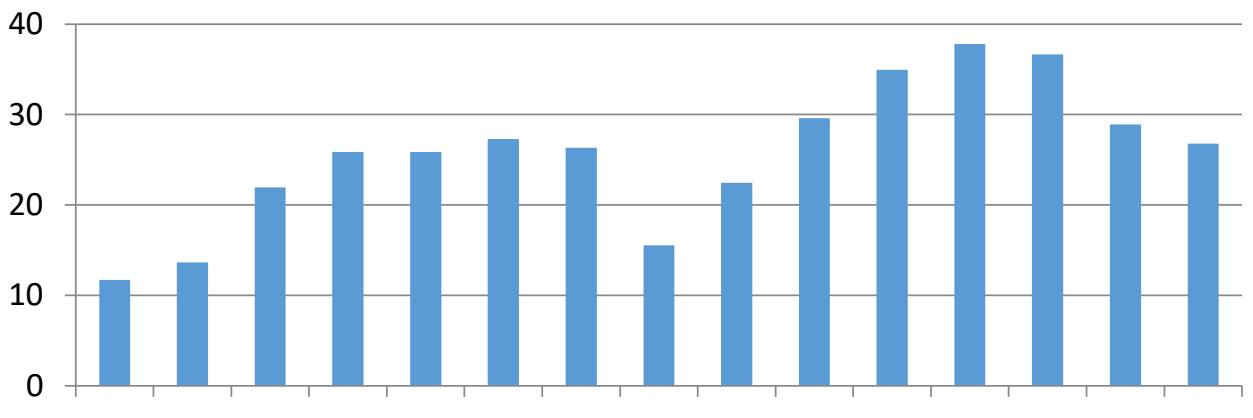

Control of Corrup

199619981999200020022003200420052006200720082009201020112012

Figure 1: Control of Corruption Yearly Percentile Change Albania (1996-2012)

According to Global Corruption Barometer of $201350 \%$ of respondents say that corruption is a serious problem in this country, $70 \%$ of them responded that education systems are extremely corrupt and $80 \%$ say that medical and health services are extremely corrupt (Transparency International, 2013).

\section{Forms of Corruption}

As mentioned above corruption is a wide spread phenomenon in Albania. Country is perceived as highly corrupted. Among all the forms of corruption in world, in the country petty and bureaucratic corruption is the most observed one. It should be also mentioned that organized crime, is another form of corruption, that Albania is trying to fight with .Because of corruption Albania's progress development has been hindered.

Petty and Bureaucratic Corruption

This type of corruption is the most widespread one in Albania. Public officials are very corrupted and this puts a great load on business firms.

Interpreting Table 1 we can see that business firms pay bribes to public officials to perform a business transaction. Compared with Central Europe and Eastern Asia percentage of bribes being paid by businesses in Albania is higher. for example in Europe and Central Asia Percentage of firms expected to give gifts in meeting with tax officials is 9.8, while in Albania it is 18.4. The same thing is observed even with other indicators listed in Table1 (Enterprise Surveys, 2013). Small businesses are those that pay more bribes. The most common way of paying bribes is cash. According to results of Enterprise Surveys purpose of speeding up the business procedure is what mostly pushes businesses to use bribes. 13.5 $\%$ percent of bribes being paid to public officials are not used for immediate results, but to serve them in the future in case they need something.

\section{Political Corruption}

Electoral deception is one of the biggest problems in Albania. for example in 2007 local elections there were observed some problems with voter's registrations. While in the elections if 2009 Freedom House states that even though there were not noticed many major problems, vote counting process was doubtfully seen by Socialist Party and was followed by legal disputes. Besides these a serious problem is the not reporting of political party's income and their source of funding during electoral campaigns.

\section{Organized Crime}

Nearly $50 \%$ of Albanian GDP comes from illegal activities such as: drug trade, prostitution and smuggling. A very serious problem is the drug trade. Lazarat, a village in Gjirokastra, south of Albania is the biggest drug suppliers. Drug trade is the main source of living for people in that area and police finds it very difficult to penetrate in there. Several scandals are reported recently by the media regarding this phenomenon. Media is revealing the fact that behind this situation stay some powerful politicians. 


\section{Methodology \& Data}

The data used in this paper correspond to the period of 2000 until 2012. This sample has data about corruption, poverty, economic growth and gender inequality.

This paper uses Control of Corruption Index of World Bank as a measure of public corruption. It is used to understand people perception's of how much public power is used for personal benefits. It includes both petty and grand corruption. Data for this index is taken from 31 different sources produced by surveys conducted by NGOs, national and international organizations, private firms etc. Score range varies from -2.5 to 2.5 , with -2.5 for the worst performance and 2.5 for the best performance. A high score serves as a signal for a positive performance of government in reducing or control of corruption. Control of corruption is given as a percentile rank. This percentile rank shows the percentage of countries in the world which score below the selected country. It is based on 0 to 100 scale. 0 corresponds to the lowest rank while 100 to the highest rank.

Annual GDP growth rate is used to estimate the relationship that exists between economic growth and corruption. GDP growth rate shows percentage change of a country's GDP from one year to another. It is expected that with a higher economic growth corruption decreases. Besides this, FDI is also is used in examining the relationship between corruption and economic growth. World Bank defines FDI as sum of net inflows of investments not on a single investor, but instead on a venture operating in a country.

To examine the relationship between corruption and poverty, unemployment rate and GNI per capita are used. GNI per capita is the ratio of Gross National Income of a specific country divided by the mid-year number of population of that country. It is calculated in American dollars. It is expected that a higher GNI per capita ratio will affect positively corruption, by decreasing it. On the other hand an increase in unemployment rate is believed to affect negatively on corruption, by increasing it.

The relationship between corruption and gender is studied through two main variables, number of women in parliamentary positions and women's share of labor force.

To examine the link between corruption, economic growth, poverty and gender inequality a regression analysis has been performed. Control of corruption variable from the World Bank is used as the dependent variable.

Independent variables are five: Annual GDP growth rate, GDP per capita, Unemployment rate, Number of women in parliamentary positions and women's share in the labor force.

In Table2 are the data used in the regression analysis to empirically study the effect that variables have on each other. This paper has 12 observations for each variable. The data for the analysis has been accessed from World Bank database.

\section{Analysis}

$\mathrm{CC}=\beta_{0}+\beta_{1} *$ FDI $+\beta_{2} *$ GDPgr $+\beta_{3} *$ GNIpC $+\beta_{4} *$ UnR $+\beta_{5} *$ PrWLeg $+\beta_{6} *$ WShLF $+u$

This is the equation showing the relationship of corruption with economic growth, poverty and gender inequality.

Where CC stands for the dependent variable, which in this paper is the control of corruption. It is the variable to be predicted.

$\beta_{0}$ : is the expected intercept parameter. It equals $Y$ when the values of the independent variables are 0 . It is called as the $Y$-intercept of the line.

$\beta_{1}$ : is the slope of regression line, with respect to $x 1$. It shows how much $Y$ changes with one unit change in $x 1$.

FDI: is the first independent variable and in this case is Foreign Direct Investments in Albania.

$\beta_{2}$ : is the slope of the regression line, with respect to $\times 2$. It shows how much will $Y$ change with one unit change in $x 2$.

GDPGr: is the second explanatory variable and corresponds to economic growth rate in Albania/

$\beta_{3}$ : is the slope of the regression line, with respect to $\times 3$. It shows how much will $Y$ change with one unit change in $\times 3$.

GNIpC: is the third independent variable and corresponds to data about Gross National Income per capita.

$\beta_{4}$ : is the slope of the regression line, with respect to $x 4$. It shows how much $Y$ will change when $x 4$ is changed by one unit. 
UnR: is the 4th independent variable used in this model, and are the data about unemployment rate in Albania.

$\beta_{5}$ : is the slope of the regression line, with respect to $x 5$. It shows the effect that one unit change in $x 5$ has on $Y$.

PrWomPar: is the 5th explanatory variable used in this model, and is about proportion of women in parliamentary positions.

$\beta_{6}$ : is the slope of regression line with respect to $x 6$. It shows how much $Y$ changes with one unit change in $x 6$.

WShaLFPR: is the 6th independent variable and is about the women's share in labor force.

$\mathrm{U}$ : stands for the error term.

\section{The following table summarizes output results from the regression analysis.}

In the interpretation of Table 3, CC has a mean of -0.6867 , meaning that on average the performance of government in control of corruption was negative. The standard deviation of CC is 0.12558 , explaining that on average data about CC vary by 0.12558 from the mean.

FDI has a mean of $\$ 695354189.4333$ per year in Albania and on average the values in the data set vary with $\$ 521236485.04032$.

GDP growth rate has a mean of 4.7750 and a standard deviation of 1.89359. This standard deviation shows that GDP growth has been relatively stable for this period.

GNI per capita has a mean of $\$ 6987.5$ and on average the values of data used in this model vary with $\$ 1817.75$.

Mean of unemployment rate is 13.36 which is not a good indicator. Standard deviation of unemployment rate is 0.7655 which shows that unemployment rate has been almost stable and high during the period being studied.

Proportion of Women in Parliament has a mean of $9.633 \%$. On average data on this model vary by $4.78 \%$.

Mean of Women's share in labor force participation rate is $47.5 \%$ and has a standard deviation of $2.34 \%$.

In Table 4 are presented the correlations among variables used in this analysis.

Among all variables the ones having the highest correlation with CC are FDI, GNI per capita and Women's share in labor force participation rate. FDI has a positive and a relatively strong relationship with control of corruption. Correlation between them is 0.785 . When FDI in Albania increase CC is expected to improve, indicating a lower corruption level in the country. The correlation between GNI per Capita and CC is relatively strong and positive, 0.716 . When GNI per capita increase CC is expected to increase and corruption in the country is expected to decrease. Regarding the correlation between Women's share in labor force participation rate and CC a strong but negative relationship is observed. The correlation coefficient is 0.756. An increase in women's share labor force participation rate is expected to decrease CC, suggesting a higher corruption level in Albania. Regarding correlation between CC and Proportion of women holding a seat in the parliament a moderately strong and positive relationship is observed. When number of women in parliament increases an increase in $\mathrm{CC}$ is expected. The weakest correlation is observed between corruption and GDP growth rate. Correlation coefficient is 0.082 . It is a weak and negative relationship, implying almost no relationship between these two variables. The correlation between unemployment rate and $\mathrm{CC}$ is also moderately weak, but positive.

Accordingly, the correlations that exist among independent variables in this dataset are explained. From the results of the table above FDI has strongest relationship with GNP per capita and Women's share in labor force participation rate. Correlation between GNI per capita and FDI is 0.944 . It implies a very strong and positive relationship. When GNI per capita is increasing, FDI is increasing, too. Correlation coefficient between FDI and Women's share in the labor force participation rate is -0.921 . It shows a strong, but negative relationship between the two. An increase in women's share labor force participation rate is expected to decrease FDIs in the country. The weakest correlation of FDI is with GDP growth rate. Correlation coefficient is -0.417 . This implies a moderately weak and negative relationship between these two variables. When GDP growth rate increases level of FDI is expected to decrease. On the other hand GDP growth has the strongest relationship with Proportion of Women having a seat in the parliament. A moderately strong and negative correlation is observed, -0.726 . With an increase in the number of women in parliament GDP growth rate is expected to decrease. The results show that GDP growth has the weakest correlation with women share in labor force participation rate. The correlation coefficient is 0.431 , suggesting a moderately weak and positive relationship. GNI per capita has the strongest correlation with women's share in labor force participation rate. A correlation coefficient of -0.993 , implies a very strong, but negative relationship among these two variables. An increase in of women in labor force is decreasing GNI per capita. The correlation of GNI per capita with all other independent variables is seen to be positive and relatively strong. Regarding the correlation of Unemployment rate with other independent variables the strongest correlation is observed with the number of women holding a position in parliament. The correlation coefficient of 0.812 suggests a relatively strong and positive relationship 
among them. When number of women in parliamentary positions is increased, unemployment rate is expected to increase also. Unemployment rate has the weakest correlation with women in labor force participation rate variable. However, this correlation is not weak, but close to 0.5 . The correlation is negative. As discussed above women's share in labor force has a very strong and negative correlation with GNI per capita. Its correlation with GDP growth rate is seen to be weak but positive, suggesting an increase in either of the variables when one of them increases.

From the output of Table 5 by use of coefficient of determination R2 goodness of fit is measured. Coefficient of determination shows how much variation of the dependent variable is explained by the regression line and explanatory variables. in this model $97.6 \%$ of variation of government performance in control of corruption variation, the dependent variable, is explained by the independent variables. $2.4 \%$ of variation is not explained. $\mathrm{R} 2$ in multiple regression does not take into consideration the degrees of freedom used in the model. It faces the problem of over fitting. A more accurate value is the adjusted R2. Adjusted R2 in the model is approximately 0.948237 . It shows that actually approximately $94.8 \%$ of variation in $Y$ is explained by the independent variables. R2 and adjusted R2 are very close to each other. This is a very good indicator, as it suggests that over fitting problem is almost not present in this model.

Interpreting the results of Table 6, F-test regarding the significance of the model is conducted. for the model to be statistically significant Sig. or probability of F-statistics ( $p$ ) should be less or equal to the level of confidence. in this model significance level is 0.05 and $p$ is 0.001 . $p=0.001<0.05$, so the model is statistically significant. It means that in Albania government performance in control of corruption has statistically significant relationship with the explanatory variables. When df $1=6$ and $\mathrm{df} 2=5$ and confidence level is 0.05 , critical value for $F$ is calculated to be approximately 4.95 . in order for the model to be statistically significant $F$ statistics must be value than $F$ critical value. in this case $F$-statistics $=34.585$, which greater than 4.95 , showing that the model is statistically significant.

Interpreting Table 7 the following regression equation is obtained:

Equation 1: Regression Equation

$$
\begin{gathered}
\widehat{\mathrm{Y}}=19.37+(6.02 \mathrm{E}-10) * \mathrm{FDI}+(-0.021) * \mathrm{GDPgr}+(-0.001) * \mathrm{GNIpC}+(-0.033) * \mathrm{UnR} \\
+(-0.009) * \mathrm{PrWLEg}+(-0.34) * \mathrm{WShLFPr}+\mathrm{u}
\end{gathered}
$$

After finding that the model is statistically significant, significance of coefficients with the dependent variable is measured. In order to test the significance of the coefficients the following hypothesis are used:

$\mathrm{H} 0: \beta=0$

$H 1: \beta \neq 0$

These hypothesis test if independent variables have a statistically significant effect on the dependent variable or not. If the probability of the t-statistic for the corresponding coefficient is less than or equal to confidence level, null hypothesis is rejected. in this model significance level is 0.05 . The hypothesis is a two-tailed one. Another way to test the significance of the coefficients is the comparison of t-statistics with the critical value. The critical value in this model is \pm 1.96 . in order for the coefficients to be significant t-statistics of each of them must be larger than 1.96 or less than -1.96 .

$\mathrm{t}$-statisticsFDI $=6.11$ and probability for $\mathrm{t}$ statistics for $\mathrm{FDI}$ is 0.002 . Confidence level is larger than $p(0.05>0.0017)$. The null hypothesis will be rejected, meaning that there is a statistically significant relationship between corruption and FDI in Albania. When comparing t-statistics with critical value we can see that there is a statistically significant relationship between corruption and FDI (t-statisticsFDI=6.11>1.96).

$t$-statisticsGDPgrRat=-1.653 and probability of the t-statistic to be like this for GDPgrRat is 0.159 . Confidence level is smaller than $p(0.05<0.159)$. This means that there is no statistically significant relationship between GDP growth rate and corruption in Albania. This insignificance can be as a result of the scope of the economy in Albania. As it is small economy the effect of GDP growth rate in control of corruption is not high. This insignificant relationship can be also observed when comparing t-statistics with critical value. $t$-statisticsGDPgrRat=-1.653>-1.96, so statistically there is no significant relationship between the two.

t-statisticsGNIpCapita=-6.019 and the probability of the t-statistics to be like this is 0.0018 . Probability of t-statistics 0.0018 is smaller than confidence level 0.05 . As a result there is found a statistically significant relationship between GNI per capita and control of corruption in Albania. t-statisticsGNIpCapita=-6.019<-1.96, indicating a statistically non-significant relationship between GNI per capita and control of corruption in Albania.

$\mathrm{t}$-statisticsUnRate $=-1.441$ and the probability for it is 0.20 . The probability of t-statistics is larger than the confidence level $(0.20>0.05)$. There is no statistically significant relationship between corruption and unemployment rate in Albania. in 
Albania the political and grand corruption comprise the highest percentage of total corruption. Thus unemployment, which is mostly seen in that part of population having no relationship with politics, is found to be statistically insignificant. Even when $t$ test is made the relationship is found to be insignificant. $t$-statistics UnRate=-1.441>-1.96.

t-statisticsPofWinParl.Pos=-1.061 and the probability of t-statistics is 0.337 . The probability of t-statistics is larger than the confidence level $(0.337>0.05)$. From the results is seen that relationship between proportion of women in parliamentary position and corruption is statistically insignificant in Albania. This insignificance can be explained through two factors. The first one is that the number of women as legislators in Albania, despite the increase year by year, is not high enough to have a significant impact. A second reason is that women used to have limited access to higher positions in parliament. These higher positions usually are held by men, who are the ones that control and direct those women holding a place in parliament. t-statisticsPofWinParl.Pos=-1.061>-1.96, which shows a statistically insignificant relationship between the two.

$\mathrm{t}$-statisticswshLF $=-5.863$ and probability for t-statistics is 0.002 . Probability of t-statistics for women's share in labor force is smaller than confidence level $(0.002<0.005)$. There is a statistical significant relationship between women's share in labor force and corruption in Albania. When making t-test t-statisticswshLF=-5.863<-1.96, indicating a statistically insignificant relationship between women's share in labor force participation rate and corruption.

The following paragraphs consist on an interpretation of Beta coefficients resulting from the analysis.

$\beta_{1}=.6 .02 \mathrm{E}-10$. This coefficient shows that the relationship between control of corruption index and FDI is positive. With one dollar change in FDI, control of corruption index score will change by $6.02 \mathrm{E}-10$ units. A positive relationship shows that when the level of FDI in Albania increases government performance in control of corruption improves. The reason behind this positive relationship is explained by the fact that FDIs are not controlled and influenced by Albanian bodies, which are perceived to be highly corrupt.

$\beta_{2}=-0.021$. A beta coefficient of -0.021 shows a negative relationship between government performance in control of corruption and GDP growth rate. With one percent increase in GDP growth rate, CC score will decrease by 0.021 units. in the case of Albania an increase of GDP growth rate means more resources available in the hand of corrupted bodies, so that they use these resources in a way that benefits them more.

$\beta_{3}=-0.001$. This beta result shows that the relationship between CC index and GNI per capita is negative. With one dollar increase in GNI per capita CC index decreases by 0.001 units. Albanians have the perception that almost every sector in Albania is very corrupted and those having more money on their hands benefit more from different public and private services. Because of this perception with an increase in income level of the individuals bribes increase and it becomes more difficult for the government to control corruption.

$\beta_{4}=-0.033$. The link between unemployment rate and $C C$ is found to be negative. When unemployment rate increases with one percent CC's score decreases by 0.033 units. When unemployment increases people's contentment with the government is low and they don't believe on the fairness of government. Because of this government performance in control of corruption worsens.

$\beta_{5}=-0.009$. The relationship between $\mathrm{CC}$ and proportion of parliamentary positions occupied by women is found to be negative in Albania. With one percent increase in the number of women in the parliament $C C$ decreases by 0.009 , meaning that government performance in control of corruption does not improve.

$\beta_{6}=-0.34$. Even the relationship between $C C$ and women's share in labor force is found to be negative. With one percent increase in number of women in labor force $\mathrm{CC}$ decreases by 0.34 units, suggesting that government performance in control of corruption worsens.

Behind the findings that the link between CC and women's share in labor force and proportion of women in parliamentary positions is negatively, lays the fact that women are easily corrupted. They are corrupted easily due to the fact that they have less power in their hands so that they can behave differently from the environment they work in. in all-male network, where the network is perceived to be highly corrupted, there is not left enough space for women to deviate from this socalled 'culture'.

In order to understand the sensitivity of dependent variable to changes in the independent variables an interpretation of standardized beta coefficients is made.

With one standard deviation increase in FDI, CC will increase by 2.498 standard deviations. One standard deviation increase in GDP growth rate will decrease $\mathrm{CC}$ by 0.322 standard deviations. in case of one standard deviation increase in GDP per capita, CC will decrease by 7.689 standard deviations. When unemployment increases by one standard deviation $\mathrm{CC}$ will decrease by 0.204 standard deviations. $\mathrm{CC}$ will decrease by 0.327 standard deviations when proportion of women 
parliamentary positions is increased by one standard deviation. And, with one standard deviation increase in women's share in labor force participation rate CC will decrease by 6.338 standard deviations.

\section{Conclusion}

This paper discussed one the most debated topics of today's world, corruption. Corruption is a widespread phenomenon present in every country in the world, even though in different levels. It is very difficult to measure it, because it is not reported as it is an illegal activity. The main objective of this paper was to study the effect that economic growth, poverty and gender inequality have on corruption, especially in Albania. A regression analysis was conducted, where CC was the dependent variable and FDI, GDP growth rate, GNI per capita, Unemployment rate, Proportion of women having a seat in the parliament and Women's share in labor force participation rate were used as independent variables. From the analysis it resulted that only FDI, GNI per capita and Women's share in labor force participation rate have a statistically significant relationship with corruption. Others resulted to be statistically insignificant. An increase in FDI improves government performance in control of corruption. When GNI per capita increases CC score decreases, resulting in higher corruption levels in the country. This can be explained by the fact that institutions and people on general are perceived to be highly corrupted. When people have more money on their hands, they use this power to get what they want. The results also showed that with an increase in the number of women in labor force participation rate, holding other factors fixed, government gets a lower score in the control of corruption.

\section{References}

[1] Alaman, S. (1989). Anatomy of Corruption: An Approach to the Political Economy of Underdevelopment. American Journal of Economics and Sociology , 441-456.

[2] Alatas, V. (2008). "Gender, Culture, and Corruption: Insights from an Experimental Analysis. Southern Economic Journal , NA.

[3] Bendardaf, I. O. (1996). The Macroeconomic Analysis of the Effects of Corruption on Economic Growth of Developing Economies. Rivista Internazionale di Sciencze Ecomiche e Commerciali , 191-211.

[4] Brunetti, A. (1999). Credibility of Rules and Economic Growth - Evidence from a World Wide Private Sector Survey. Washington DC: World Bank.

[5] C.North, D. (1991). Institutions. The Journal Of Economic Perspectives , 97-112.

[6] Chetwynd, E., Chetwynd, F., \& Spector, B. (2003). Corruption and Poverty: A Review of Recent Literature. Washington DC: NA.

[7] Dollar et.Al, D. (1999). Are Women Really the Fairer Sex? Corruption and Women in Government. World Bank , NA.

[8] Enterprise Surveys. (2013, NA NA). Enterprise Surveys. Retrieved May 30, 2014, from Enterprise Surveys: http://www.enterprisesurveys.org/

[9] Farida, M., \& Ahmadi-Esfahani, F. Z. (2006). Corruption and Economic Growth in Lebanon. Australian Agricultural and Resource Economics Society 52nd Annual Conference (p. NA). NA: NA.

[10] Goetz, A.-M. (2004). Political Cleaners: How Women are the New Anti-Corruption Force. Does the Evidence Wash? NA, NA.

[11] Gupta, S., Davoodi, H., \& Alonso Terme, R. (1998). Does Corruption Affect Income Inequality and Poverty? IMF Working Paper , 23-45.

[12] Gyimah-Brempong, K. (2002). Corruption, Economic Growth, and Income Inequality in Africa. Economics of Governance, 183-209.

[13] Investopedia. (NA, NA NA). Investopedia. Retrieved April 04, 2014, from Investopedia: http://www.investopedia.com/

[14] Kariuki, N. w. (2008). "Impact of Corruption on Women's Economic Empowerment in Africa. NA, NA.

[15] Karstedt, S. (2001). The Culture of Inequality and Corruption: A Cross-National Study of Corruption. NA: Australian Institute of Criminology. 
[16] Lambsdorff, J. G. (1999). Corruption in Empirical Research. 9th International Anti-Corruption (p. NA). Durban, South Africa: NA.

[17] Lanch, S., \& Rob, R. (1992). R\&D, Investment and Industry Dynamics. NBER Working Papers , ALI.

[18] Leff. (1989). Economic Development through Bureaucratic corruption. in Heidenheimer, Johnson, \& Levine, Political Corruption: A handbook (pp. 389-403). New Brunswick: NA.

[19] Leff, N. (1964). Economic Development through Bureaucratic Corruption. American Behavioral Scientist, NA.

[20] Lui, F. (1985). An Equilibrium Queuing Model of Bribery. Journal of Political Economy , 760-781.

[21] Mauro, P. (1995). Corruption and growth. Quarterly Journal of Economics , 681-712.

[22] Mikkola, A., \& A.Miles, C. (2007). Development and Gender Equality: Consequences,causes, challenges and cures. Helsinki Center of Economic Research , 7-11.

[23] Misturelli, F., \& Heffernan, C. (2008). What is poverty? A dischronic exploration of the discourse on poverty from the 1970s to the 2000s. The European Journal of Development and Research , 666-684.

[24] Mo, P. H. (2001). Corruption and Economic Growth. Journal of Comparative Economics , 66-79.

[25] Nawaz, F. (2009). State of Research on Gender and Corruption. NA: Anti-Corruption Resource Center.

[26] O.Krueger, A. (1974). The Political Economy of Rent-Seeking Society. The American Economic Review , 291303.

[27] Robinson, M. (1998). Corruption and Development: An Introduction. The European Journal of Development Research , 1-14.

[28] Roys, N., \& Seshadri, A. (2014). On the origin and casuses of economic growth. The Social Systems Research Institute (SSRI) , 4-5.

[29] Scott, J. C. (1972). Comparative Political Corruption. NA, NA.

[30] Shah, A. (2013, March 24). Global Issues. Retrieved April 02, 2014, from Global Issues: http://www.globalissues.org/issue/2/causes-of-poverty

[31] Shah, A. (2013, March 24). Global Issues. Retrieved April 02, 2014, from Global Issues: http://www.globalissues.org/issue/2/causes-of-poverty

[32] Sung, H.-E. (2003). Fairer Sex or Fairer System? Gender and Corruption Revisited. Journal of Development Economics , 25-55.

[33] Swamy, A., Knack, S., Lee, Y., \& Azfar, O. (2001). Gender and Corruption. Journal of Development Economics , 25-55.

[34] Transparency International. (1993, May NA). Transparency International. Retrieved March 28, 2014, from Transparency International: http://www.transparency.org/whatwedo

[35] Transparency International. (2013, NA NA). Transparency International. Retrieved April 06, 2014, from Transparency International: http://www.transparency.org/country\#LUX

[36] TransparencyInternational. (1993, May NA). Transparency International. Retrieved March 28, 2014, from Transparency International: http://www.transparency.org/whatwedo

[37] Treisman, D. (2000). The causes of corruption: A cross-national study. Journal of Public Economics , 339-457.

[38] Trip, A. (2001). Women's Movements and Challenges to Neopatrimonial Rule: Preliminary Observation from Africa. Development and Change , 33-54.

[39] United Nations. (2001, NA NA). United Nations. Retrieved April 04, 2014, from United Nations Entity for Gender Equality and Empowerment of Women: http://www.unwomen.org/

[40] USAID. (2005). Anticorruption Strategy. Washington DC: USAID.

[41] World Bank. (2009). Albania Country Profile. NA: World Bank.

[42] World Bank. (2000). Making Transition Work for Everyone: Poverty and Inequality in Europe and Central Asia. Washington DC: World Bank. 
[43] World Bank. (1997). WDR 1997 : The State in a Changing World. New York: World Bank and Oxford University Press.

[44] World Bank. (2012, NA NA). World Bank. Retrieved May 30, 2014, from World Bank Web site: http://www.worldbank.org/en/country/albania

[45] WorldBank, T. (1997). WDR 1997 : The State in a Changing World. New York: World Bank and Oxford University Press.

[46] You, J.-S., \& Khagram, S. (2004). Inequality and Corruption. KSG Working Paper , 1-59.

\section{Tables}

Table 5. Model Summary

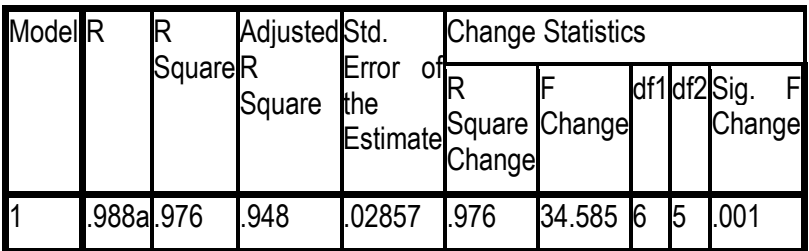

a. Predictors: (Constant), WomenShareLFPR, GDPGrowth, Unemployment, PropWomenPar, FDI, GNIperCap

Table 6. Anova

\begin{tabular}{|ll|l|l|l|l|l|}
\hline Model & & Sum of Squares & Df & Mean Square & Sig. \\
\hline \multirow{3}{*}{1} & Regression & 169 & 6 & .028 & 34.585 & $.001 \mathrm{~b}$ \\
& Residual & .004 & 5 & .001 & & \\
& Total & .173 & 11 & & & \\
\hline
\end{tabular}

Table 7: Coefficientsa

\begin{tabular}{|c|c|c|c|c|c|c|}
\hline \multirow[t]{2}{*}{ Mod } & & \multicolumn{2}{|c|}{ Unstandardized Coefficients } & \multirow{2}{*}{\begin{tabular}{|l}
$\begin{array}{l}\text { Standardized } \\
\text { Coefficients }\end{array}$ \\
Beta
\end{tabular}} & $\mathrm{t}$ & \multirow[t]{2}{*}{ Sig. } \\
\hline & & $B$ & Std. Error & & & \\
\hline \multirow{7}{*}{1} & (Constant) & 19.377 & 3.348 & & 5.787 & .002 \\
\hline & FDI & 6.019E-010 & .000 & 2.498 & 6.116 & .002 \\
\hline & GDPGr & -.021 & .013 & -.322 & -1.653 & 159 \\
\hline & GNIpC & -.001 & .000 & -7.689 & -6.019 & .002 \\
\hline & UnR & -.033 & .023 & -.204 & -1.441 & .209 \\
\hline & PrWLeg & -.009 & .008 & -.327 & -1.061 & 337 \\
\hline & WShLFPR & -.340 & .058 & -6.338 & -5.863 & .002 \\
\hline
\end{tabular}

a. Dependent Variable: Corruption 